\title{
From the Thesis of the Colonial Situation to the Antithesis of Colonial Independence: Where is our Synthesis
}

\author{
Uhembe Clement Ahar
}

Department of Political Science

Federal University Lafia PMB 146 Lafia, Nasarawa State, Nigeria

clemkange@gmail.com

Abstract: In spite of many years of slave trade in Africa, this paper finds relevant contemporary political economy relationship with the current politics of development and under development in Africa with Europe. The paper, by way of political economy analysis, argues that Europe did not start the slave trade. African societies had sold slaves to each other for centuries and for export to North Africa and Asia across the Sahara through Ethiopia and the Azanian ports. However, the flow of slave across the Indian Ocean was very minimal compared with transatlantic trade. It is the sheer volume of the slave traffic across the Atlantic and the brutality/the current impact that has continued to affect Africans that this paper investigates. The paper interrogates the ideological metamorphosis of nomenclature to globalization and capitalism and examines its implication in our contemporary society with particular reference to Nigeria and recommends that the issue be readdressed in the light of the presentcapitalism. Keywords: Development, capitalism, imperialism, slave trade

INTRODUCTION

Before the $15^{\text {th }}$ century, Europeans had very little direct contact with Africa because of lack of knowledge. For centuries, Europeans traded with Africans along Africans coasts. They did not attempt any foray into the interior part of Africa.

Africa is said to have no history. For centuries, it was a deep belief in America and Europe that the despised black men of Africa had languished in savagery for thousands of years. Ferguson (1992) could not agree less when he stated that, this myth continued even till the (20 $2{ }^{\text {th }}$ Century; in 1952 (less than 60 years ago).

When the European power divided Africa into spheres of influence in 1885, it was under the pretext of bringing development. Whereas the true aim was imposition of imperialism, put like a righteous campaign to bring the benefits of development to the supposedly wretched Negro savages. Lord Milverton, a former colonial governor of Kenya in 1903, said that the African has stagnated in primitive savagery during thousands of years that men in the rest of the world were creating their civilizations. The whole generations of African school children were taught that they had no past. This sociological educational underdevelopment can be measured from this premise, if a medical doctor makes a mistake in operating a patient, it is only the patient that will die, in the same vain, if a lawyer makes a mistake in defending his client in court, only the client will go to jail, but when wrong education is given to a generation, (that Africans has no past) the whole of the generation perish.

The argument of this paper therefore, is beyond econometric materialism. European attitudes about Africans developed into a complex set of derogatory myths. Africa was depicted as a dark continent of jungles and dank, mysterious swamps, and Africans were thought of as savages with no history and no 'culture'. Europeans ignorance of the African interior contributed to the myth of African inferiority, but the slave trade played the more active role in creating these myths. 
From the Thesis of the Colonial Situation to the Antithesis of Colonial Independence: Where is our Synthesis

This paper argues that Africa can lay claims to their under development after so many years of decolonization and abolition of slave trade. According to sugarcane planter, Edward Long, Africans were devoid of genius, and seem almost incapable of making any progress in civility or science. They have no plan or system of morality among them, James Bostrell, another British official said Negroes are oppressed, since Africa's sons were always slaves.

Pan Africanism as a Revolutionary movement was a concept rooted in the doctrine and principles of Africans reposing themselves culturally and materially. The founding father of Pan Africanism was Marcus gerbey. Born in Jamaica in 1887, garvey went to London in 1912 where he met Africans from the British possession and was confirmed in his belief that oppression of blackman everywhere was related to that colonisation of Africa. In 1914 Garbey returned to Zamiu and founded the universal negro improvement association with the aim of uniting all the negor peoples of the world into one graet body to establish a country and government of their own. This is the background of a situation that founded the bases of discussion and finding in the paper.

The event of 1916 to 1919 following his return and settlement in America where his ideas spread and crystallised coincided with the summer of the year some American white raged through American cities, namely in the North, shooting and assaulting, Negroes burning and looting their properties.

Marcus garvey Appeased to the frustration of these negroes. It was not all rhetoric, for Garvey established the infrastructure that could help the Negroes free themselves from white domination. These were the back start steamship line, the universal African legion, the Universal black cross nurses, the African Orthodox Church; the Negro world (magazine) etc. the message was loud and clear despite the failure of some of these projects due to both internal and external contradiction arising from mismanagement and machination of American Authorities

Garvey (1921) message was very clear: 'Black men, you were once seat; you shall be great again. Lose not courage, lose not faith, and go forward. The thing to do is to get organised; keep separated and you will be exploited, you will be robbed. You will be killed. Get organised, and you will compel the world to respect you. If the world fails to give you consideration, because you are black men, because you are Negroes, four hundred million of you shall, through organization, shake the pillars of the universe and bring down creation, even as Samson brought down the temple upon his head and upon the head of the Philippines' This message was heard by both Americans and Negroes in London.

\section{THE THESIS}

All Pan Africanist recognised they have certain things in common. They recognised that they are persons of one race, of a common historical background, and of a common identity. They are of a race whose culture, wealth, and personality have been taken away. They were all alienated by peoples of one race. They were alienated in America, in Nigeria, In Ghana, in Haiti, in Jamaica, and in other places. Their alienators, exploiters, oppressors and colonisers are Europeans peoples and their descendants there are peoples achieved their greatness by sitting on African and Asian people. But for the piracy the so called exploration, the raw materials as the labour of the dominatedAsian and African peoples the western industrial revolution could have been a great success and but for the market provided by Asian and African people for industrial products of the western world white race would have not been able to maintain their hegemony on black and yellow paces.

This paper argues that this was the thesis of the world situation in a more logical way presented worth endurance in order to prove that it is true. Very central to this was that African countries pioneered the Negro intellectual interest in Africa appreciation of race. They advocated types of pragmatic nationalism for the Negroes protection, and for long development and growth in intelligence and efficiency.

African like Du Bois Attended the universal race congress at London in1911, and promoted five pan African conferences the first in 1919 at Paris, and the last in 1945 at Manchester although, some of the pan Africanist 
From the Thesis of the Colonial Situation to the Antithesis of Colonial Independence: Where is our Synthesis

were separated from their mother country, the binding ties was that they all recognised that this great human tragedy did not remove the common identity.

\section{ANTITHESIS}

The antithesis of the struggle for national independence by this paper starts from the struggles for national independence to the events of post-independence. It starts from the twenties when few Africans sons and daughters got together and decided to drive out the colonial rulers from their fatherland. These African said in effect, we must get the white exploiter off our banks and the whiteman must go home'

The colonisers were attacked in Ghana (gold coast) in Guinea, in Jamaica, in Nigeria, in Haiti, in Zululand, in Guyana, in Trinidad, in Nyasaland, in Congo, and in other colonies. They were attacked by almost simultaneously, one attack after another; ideas were exchange between African people in America, in the West Indies and those on the continent of Africa.

The paper argues that this was what marked the beginning or the cutting age in which African wanted to take their destinies in the own hand. The tide of Pan Africanism as a revolutionary movement swept through, the boundaries created by the colonizers started crumbling. The thesis became antithesis; Du Bois founded no difficulty in commencing with Dr. Azikwe; George Padmore was ever so close to Nkrumah. Dr. Banda created contact with the early Pan Africanist Garvey symbolised the trinity of African peoples in the Westindies

One major event that marked the contradiction that help dismounted colonisation was in the organic character of it admittance that, the whiteman said that African were savages yet the colonial masters was not frightened to come and stay with them. The one person you described as aggressive and violent, brutal and capable of causing great harm became your custodian. How could you have leave your comfort zone (Europe) to stay with a savage? Our political economic perspective in understanding this question lays in the motive of primitive exploitation by Europe and Europeans at the expense of African development.

The nexus between this explanation and the kind of resistance against foreign domination is subjective that African knew that this contact will create a depopulation of best brains that would initiate development in Africa; instigate conflicts as Africans were encourage to raid village in search of the human commodity; intra and intro communal wars will become life in a bid to conquer and cart slaves.

And that the labour force that would have engaged in development activities would certainly be diverted to security foundermentally was the treatment given to the slave who made them to develop inferiority complex and for African to see Europeans as superior race. The summary of it is that slave trade was an inhuman and exploitative business that benefited only the Europeans who became more savage.

Lest we forget, Africans resistance against foreign domination did not start with the struggle for independence it started right from the time the Dutch and Portuguese pirate. Set their feet on African soil. These were the fair beneficiaries of the ocean going theology in the postcolonial merchant's era.

We can recall the heroic struggles of king Jaja of Opobo, the King of Aros, the Alafin of Oyo, and theOba of Benin in Nigeria, the king of Dehomey, the kings of Akan and Ashanti in Ghana and other African chief. The once powerful African kingdoms of Zulu and Zimbabwe are now the strong hold of white fascism.

The paper argues that the real antithesis was in colonialism. Colonialism like any evil system createdcontradiction and sowed its own seeds for it destruction. The colonial rulers wanted some Africans to be their collaborators on the one hand, and be the spokesmen for the natives on the other hand some Africans were educated on the African tradition. They considered themselves a cut above others, as collaborators they saw the good thing of life and the pomp and powers the white administers enjoyed. As spoken for the natives they were not liked by the people, who saw them as allies in oppression, interpreters and tax collectors. 
From the Thesis of the Colonial Situation to the Antithesis of Colonial Independence: Where is our Synthesis

In the course of colonialism these educated African rebelled against their masters, producing an antithesis of post-independence from the thesis of colonial situation.

They wanted to rule their people; however, because they were the products of the system, they had to fight the enemies on their own terms and with the enemies' weapons. Pan Africanism galvanised and internationally led the struggle for power by the native intellectuals.

\section{The Point of Departures}

Some leaders of the struggle for national independence thought of political independence as an end instead of a means to an end. African had though that the synthesis would give us bread and butter, unfortunately, the new white man turned to betray the aspiration of the masses. There is today little or no bread for most people, let alone butter. Well entrenched in capitalist institution, they acquired capitalist style, attitude and consciousness. They employed all forms of neo liberal economic theories that has brought more hardship on their people worse than the once the colonial master introduce selfishness, divide and rule, crush your neighbour, survival of the fittest and moral bankruptcy

\section{THE SEARCH FOR THE SYNTHESEES}

It is a mistake to think that the present world powers can guarantee our safety. African must be world powers or live in [perpetual insecurity and uncertainty.

We still have certain things in common, we are still African peoples, sharing a common historical background, being exploited beingdisregarded, and been trampled upon by the common enemy the imperialistic and the allies in our respective countries, our task is not a surplus one. There is the problem of identifying who the real enemy is the foreign exploiters or the agents? It is no use challenging the foreign exploiters without also challenging the internal exploiters, the compradors, the elites and bad leaders.

The ability of African to free them from foreign economic, political, and cultural and technologically domination or influence can only be determined by the attitude, productivity and inventiveness of our peasant and workers.

We must aim for ideology that is based on social equality and that give man and women economic and political powers in the society.

The paper argues that we must produce our own theory. A 'theory' is an idea or belief about something arrived at through assumption and in some cases a sets of facts, proposition or principles analysed in the relation to one another especially in this case to explain phenomena of our situation. According to Cohen (1968: P2) observes that the goal of any theory is to explain something which has occurred with a new dealing with problem which arose or may arise as a result.

The point we are making here is that African have what to hold on to. As African people we are never tires of talking about our culture. Culture is an accumulated experience which modifies man in a linear progressive and quantitative manner, but with additional qualitative phases of mutation.

The result is a new man, a new society, more skilful and more apt, integrating to an ever increasing extent the means and the ends action, and perfecting to an ever greater extent technology and means of action

AfroAmerican Malcolm X (1936) observed, our history and our culture were completely destroyed when we were forcefully brought to American in Chains. And now it is important for us to know that our history did not begin with slavery's scars. We came from Africa, a great continent and a proud and variable people, and which is the new world and was the cradle of civilization.

Our culture and our history are as old as man himself and yet we know almost nothing of it.

We must recapture our heritage and our identity if we are ever to be liberated from the bond of white supremacy 
From the Thesis of the Colonial Situation to the Antithesis of Colonial Independence: Where is our Synthesis

we must launch a cultural revolution to unbrainwash an entire people, Armed with the knowledge of the past which is our thesis, we can with confidence charts a count for our future which shall be the antithesis only then can we being to see our synthesis

Culture is an indispensable weapon in the freedom struggle. African peoples need to revive those progressive elements of traditional African societies. At this stage of our development, or our underdevelopment, brothers and sisters haste each other, unemployment breeds parasites, the rich want to get richer by bribery and corruption, the poor get poorer and the young are not properly guided to make positive contribution to the society idling and loafing hare become a full time occupation for some of the youth

We must restore morality in our society by recapturing the spirit of African social system which is manifested in extended family. By extended family, we mean a way of life our ancestors bequeathed to us in which the members of the community take care of the community and the community takes care of them, the fortune and misfortune of some members of the community are shared and suffered by all, means of production are either owned or used in common, and the community.

The search for the synthesis appears to be the most difficult question, yet the answer lies within. Our reference point is Nigeria.

Nigeria has remained one nation state that dominates in fear amongst its leaders and followers. These fears have promoted corruption, bad governance and misrule. To juxtapose this assertion, Nigeria failed to get independence in the London conference of 1958 because the Northern leaders could not trust the east and the south. They took ambush in the fact that they were not prepared until 1960.

Few years after independence, (about 6 years) the military took over on account of the same fear and corruption successful,military coup, were all based on the same fear and corruption.Lack of continuity in polity adaptation and implementation was also based on fear and complain. Over the years, the country returned to democracy renewing the same fear corruption and bad governance.

Nigeria was amalgamated into a single political community in 1914 for economic, not political reason. The essence essentially was to enable the British government balance their books of account. For administrative convenience in the same direction and purpose, regional autonomy was reinforced with the division of the country into three regions. The impact of this development was that very strong ethno-regional character was introduced into Nigeria politics. (Osaghae, E.A., 2002, Uhembe, 2014).

The situation created grounds for Nigeria elites who sought to exploit it for their political ends. Looking at the disunited and disarticulated manner of the amalgamation, at every point with when the political classes felt their interest were at stake, they have not hesitated to play the trump card of secession. (Okhaide, I. P. 2012)

The regional background that saw the emergence of virtually all Nigeria parties from such associational regional development explains a lot.

1. Action Group (AG) in the west evolved from Yoruba cultural association - EgbeOmooduduwa led by Chief ObafemiAwolowo.

2. The Northern PeopleCongress (NPC) emergingfrom the Northern cultural association, JamiyyarMutanen, Drewa, led by TafawaBalewa.

3. The National Congress of Nigeria Citizens (NCNC) which started as a national party but later narrowed its social base to cultural association, called the Igbo State Union from all the above, locates the character of Nigerian federalism. 
From the Thesis of the Colonial Situation to the Antithesis of Colonial Independence: Where is our Synthesis

From this point onward, you can recall that Sardauna of Sokoto, he it was, who first referred to Nigeria as a 'mistake of 1914' wayback in the early 1950's. closely followed was a statement credited to chief ObafemiAwolowo that Nigerian was a mere geographical expression and then the later event by Zik brother to secession.

The mutual suspicion has always been the fear to date of domination of one zone over the other, that replacing European domination with Southern domination. By 1950s witness the Ibadan constitutional conference to review the Richards constitution, a representational ratio of 45 for the North, 33 for the west, 33 for the east. Northern politicians felt threatened by this arrangement and the then Emir of Zaria articulated their position clearly - the North have $50 \%$ of the seats or secede from the country. In May 1953, when the Northern politicians lost out in the political equation for opposing the AG motion for self-government in 1956, the Northern House of Assembly and the Northern House of Chiefs met and passed an Eight resolution that amounted to a call for confederation and separation.

With these development of self rather than the Nigerian State, in 1954, it was the turn of AG to demand that a secession clause be inserted in the Constitution, that was at the Lagos Constitutional conference. The move was opposed by the other two regions, the NPC and NCNC. The 1964, census and election crisis, where tree and cows in the North were accessed to have been counted to increase the figure of North, Michael Okpara, premier of the Eastern Region, directly threatened in December 1964 that the east would secede. It was at this level that Okpara went ahead to establish a committee under his attorney general to work out the modalities for a declaration of secession by Eastern Nigeria. This however did not happened until three years later by Ojukwu on a final note in 1967 to 1970 with loss of over One Million lives.

On $23^{\text {rd }}$ February 1966, Isaac Boro decided that he was not ready to live in a Nigeria that was ruled by Igbo just the same way the Igbo's felt that the country was dominated by Hausa. NPC declared the secession of the Niger Delta People Republic. The domination of the Eastern minorities by Isaac Boro started way back in his days a student activist at the University of Nigeria, Nsukka.

The Niger Delta Republic lasted for only 12 days and it took the police round up his ragtag arm of 159 volunteers. He and his colleagues were charged for treason in March and condemned to death in June 1966. When the civil war broke up in 1967.Boro Isaac was eventually released when he joined the Federal side and was killed in battle in 1968, fighting for the liberation of Rivers State from the Igbo, on the platform of the Federal Government of Nigeria.

By 1993 came another problem of June $12^{\text {th }}$ and it annulment. The Nigeria problem modified into what may appear as new formation but very original in their content - geographical groupings North-West, North east, Middle Belt, South West, East Central and Southern minority, these were called the six geographical zones. Even at these regrouping out of the three original regions where the North had contested $50 \%$, the same political equation played out with the original North with 3 zones while the east and west increased only one leaving the North with 2 additional zones to make up three out of the six geographical zones. The formation of this arrangement in Law was dropped in the transition from the 1995 to 1999 constitution.

Several conferences were held to address these fears and corruption practices that produce these bad governance to no avail have being made in most quarter for a referendum. We have adjusted the constitution many times in a manner that suggests we are moving goal post in the middle a match(Uhembe, 2015)

With UK, EU Brexit we have seen plays card like "Biafrexit". 
From the Thesis of the Colonial Situation to the Antithesis of Colonial Independence: Where is our Synthesis

\section{REFERENCES}

African Leadership Forum (2000) Farm House Dialogue- Political Parties and Good Governance in Nigeria. Dialogue 34, 7-9 April, 2000

Albert, I.O (2005) Explaining 'Godfatherism' in Nigerian Politics. African Sociological Review.9(2), 2005. pp. 79-105

Aleyomi, M. B. (2013) Intra-party Politics in Nigeria: The Case Study of Peoples Democratic Party (PDP). Journal of Sustainable Development in Africa (Vol.15, No. 4, 2013)

Okhaide, I. P. (2012) Quest for Internal Party Democracy in Nigeria: Amendment of Electoral Act 2010 as an Albatross. International Journal Peace and Development Studies Vol. 3 (3) pp. 55-75

Olaniyi, J.O. (2006) Understanding the 'epileptic' Nature of Nigerian Parties in Saliu, H.A. et al (Eds) The National Question and Some Selected Topical Issues on Nigeria. Ibadan: Vantage Publishers

Olarinmoye, 0.0. (2008) Godfathers, Political Parties and Electoral Corruption in Nigeria.African Journal of Political Science and International Relations Vol. 2(4). pp. 066-073, December 2008

Omotola, S. J, (2009) Nigerian Parties and Political Ideology. Journal of Alternative Perspective in the Social Sciences (2009) Vol. 1, No.3, 612-634

Omotola, S. J. (2010) Political Parties and the Quest for Political Stability in Nigeria. Taiwan Journal of Democracy Vol.6, No.2:125-145

Osaghae, E. A. (2002) Nigeria since Independence: Crippled Giant. Ibadan: John Archers (Publishers) Limited

Oseni, T. (2013) Internal Democracy as a Panacea to Electoral Victory. Speech Delivered at a Seminar organized by P.D.P Alimosho L.G.A, Lagos on 21st November, 2013 at RegiaLuxuria hotel and Suites, Alimosho, Lagos

Osumah, O. and Ikelegbe, A. (2009) ThePeoples Democratic Party and Governance in Nigeria.Journal of Social Science 19(3). 185-199. Kamla-Raj 20090chereome.N. (2015) How Obasanjo destroyed PDP. The vanguard newspaper (12 ${ }^{\text {th }}$ April, 2015) pp 19, April 2015

Ochereome.N. (2015) How Obasanjo destroyed PDP. The vanguard newspaper (16 ${ }^{\text {th }}$ April, 2015) pp 1, April 2015

Premium Times-Sunday August10, 2014: Stop funding political parties, CPC tells political parties

Saliu, H.A. and Muhammad A.A. (2008) Growing Nigeria's Democracy through Viable Political Parties in Saliu, H.A. et al (Eds) Perspectives on Nation-Building and Development in Nigeria. Lagos: Concept Publications

Citation: Uhembe Clement Ahar. "From the Thesis of the Colonial Situation to the Antithesis of Colonial Independence: Where is our Synthesis". American Research Journal of History and Culture ; V4, I1; pp: 1-7

Copyright (c) 2018 Uhembe Clement Ahar. This is an open access article distributed under the Creative Commons Attribution License, which permits unrestricted use, distribution, and reproduction in any medium, provided the original work is properly cited. 